\title{
Estimations Viability of LCCs Business Model in Korea
}

Author(s): Seock-Jin Hong, François Domergue

Source: Journal of International Logistics and Trade 2018; 16(1):11-20

Published by: Jungseok Research Institute of International Logistics and Trade, Inha University

DOI: https://doi.org/10.24006/jilt.2018.16.1.011

The Journal of International Logistics and Trade is an official journal published by Jungseok Research Institute of International Logistics and Trade, Inha University, Korea. JILT welcomes manuscripts that advance the practice and science of logistics, trade, and other related fields.

Frequency: Quarterly (March, June, September, December)

Stable URL: https://www.ejilt.org

The Jungseok Research Institute of International Logistics and Trade is a specialized academic research institute representing Inha University and the Inha Foundation in Korea. The institute aims to become a representative institute in Northeast Asia in the research of logistics and trade.

Stable URL: https://jrieng.inha.ac.kr

(C) Copyright. Jungseok Research Institute of International Logistics and Trade.

This is an Open-Access article distributed under the terms of the Creative Commons Attribution NonCommercial License (http://creativecommons.org/licenses/by-nc/4.0/) which permits unrestricted noncommercial use, distribution, and reproduction in any medium, provided the original work is properly cited 


\title{
Journal of
}

\section{International Logistics and Trade}

\section{Estimations Viability of LCCs Business Model in Korea}

\author{
Seock-Jin Hong ${ }^{a}$, François Domergue ${ }^{\mathrm{b}}$ \\ ${ }^{\text {a }}$ University of North Texas, Denton, Texas, USA and Kedge Business School in Bordeaux, France \\ ${ }^{\mathrm{b}}$ INSEEC Business School in Bordeaux, Hangar 19 - Quai de Bacalan - Bordeaux, France
}

\begin{abstract}
ARTICLE INFO
Article history:

Received 7 October, 2017

Accepted 29 March, 2018

Keywords:

Low-cost carriers

Airlines-within-airlines

Data envelopment analysis

Korean air carriers

Efficiency

ABSTRACT

The Korean airline industry continues to change in 20-year cycles structurally. The major changes are in their market through deregulation and liberalization resulting in adding more carriers, especially low-cost carriers (LCCs) from 2006. The authors categorize three types of LCCs in Korea: (1) independent LCCs, (2) LCCs subsidized by existing airlines as airlineswithin-airlines (AwAs), and (3) LCCs supported by conglomerates and local governments. Independent LCCs have suffered financially during the research period from 2009 to 2013, especially from the impaired capital, even though these LCCs are growing rapidly and expanding their markets in domestic and international routes. AwAs' efficiency is higher than that of independent LCCs, the roles in the market are limited because of cannibalization by their mother company.
\end{abstract}

\section{Introduction}

The airline industry of Korea continues to improve through deregulation policies and liberalization in 20-year cycles structurally. Korean Air (KE) began with the privatization of a state-run airline in 1969. From 1969 to 1988 -the initial period of the aviation industry's history in Korea-there was only one carrier in the market. During this period, the Korean aviation market expanded supply and demand in parallel with the country's economic growth. In 1988, the Korean government permitted a second carrier, Kumho, to enter the market and authorized the carrier to serve domestic routes initially and to fly international routes one year later. From 1989 to 2008, the competition between Korean Air and Asiana Airlines (OZ) increased regarding productivity and efficiency (Oum and Yu, 1997), along with the modernization of aviation authority systems. With the improved efficiency and productivity of airlines in this period, the Korean government began its open sky policy, regarding the 5th freedom and multiple designations, with the USA in 1997 and Canada in 2009. The open-air transport policy was reinforced not only beyond the 5th freedom but also regarding the bilateral deregulation of passengers and cargo with Japan, Vietnam, Thailand and China's Shandong province (Korean Ministry of Land, Infrastructure, and Transport-MOLIT, 2013). From the late 1990s, market demand within Northeast Asia has rapidly increased, with market participants providing different types of air transport services. Although no major competition has existed due to the regulatory environment for carriers entering the market, the market will increase regarding competition. In this respect, the Regulatory Reform Committee of Korea withdrew regulations in April 2008 that would have limited new carriers to operate first in only the domestic market for one year and attain a minimum of 10,000 take-offs and landings in a domestically before operating internationally. Originally, it required two years and a minimum of 20,000 take-offs and landings from 2007. With deregulation taking place in Korea, the aviation industry has entered a market of unlimited competition from multiple market entrants, especially LCCs. The influx of new carriers (Table 1) eager to build viable market share and the presence of an efficient surface transportation alternative, such as High-Speed Trains (HST) and expansion highways, has created pressure on Full-Service Carriers (FSCs). Particularly, the HST has a strong negative impact on domestic air markets (Park and Ha, 2006; Wan, Ha, Yoshida and Zhang, 2016).

\footnotetext{
* University of North Texas, 1155 Union Circle \#311396 Denton, TX 76203-5017, USA and Kedge Business School in Bordeaux 680 cours de la Liberation 33405 Talence Cedex, France; E-mail: seockjinhong@ gmail.com
} 
However, local LCCs are increasing their dominance in the domestic market, holding a sizeable $51.1 \%$ of domestic capacity share in 2014, marking the first time that LCC penetration has exceeded $50 \%$ regarding the number of passengers.

Table 1. Airlines based in Korea

\begin{tabular}{|c|c|c|c|c|c|c|c|}
\hline \multirow[b]{2}{*}{ Airlines } & \multicolumn{3}{|c|}{ Market Share $^{1)}$} & \multirow[b]{2}{*}{ Fleet } & \multirow{2}{*}{$\begin{array}{l}\text { Operations } \\
\text { started }\end{array}$} & \multirow{2}{*}{$\begin{array}{l}\text { Service } \\
\text { type }\end{array}$} & \multirow[b]{2}{*}{ Operation Base } \\
\hline & Dom & Int'l & Total & & & & \\
\hline $\begin{array}{l}\text { Korean Air } \\
\quad(\mathrm{KE})\end{array}$ & $27.8 \%$ & $29.2 \%$ & $28.9 \%$ & $\begin{array}{c}8 \text { A380, } 14 \text { B744, 34 B777, } 40 \\
\text { B737/8/9, 23 A330, } 2 \text { A360, } 4 \\
\text { B748F, } 19 \text { B744F, } 3 \text { B777F }\end{array}$ & Mar 1969 & FSC & \multirow{2}{*}{$\begin{array}{l}\text { Incheon } \\
\text { (International) } \\
\text { and Gimpo } \\
\text { (Domestic) }\end{array}$} \\
\hline $\begin{array}{c}\text { Asiana } \\
\text { Airlines (OZ) }\end{array}$ & $21.1 \%$ & $21.9 \%$ & $21.7 \%$ & $\begin{array}{c}2 \text { B } 744,2 \text { B } 747 \mathrm{C}, 12 \text { B777, } 7 \text { B767, } \\
4 \text { B737-400, } 12 \text { A330, } 10 \text { A320, } 22 \\
\text { A321, } 10 \text { B744F, } 1 \text { B767F }\end{array}$ & Dec 1988 & FSC & \\
\hline Jeju Air (7C) & $15.5 \%$ & $3.8 \%$ & $6.8 \%$ & $13 \mathrm{~B} 737-800$ & Jun 2006 & $\mathrm{LCC}^{2)}$ & Juju \\
\hline Jin Air (LJ) & $8.8 \%$ & $2.4 \%$ & $4.4 \%$ & 11 B737-800 & Jul 2008 & $\begin{array}{l}\text { LCC } \\
\text { (subsidiar } \\
\text { y of KE) }\end{array}$ & Incheon \\
\hline $\begin{array}{l}\text { Air Busan } \\
\quad(\mathrm{BX})\end{array}$ & $11.3 \%$ & $2.2 \%$ & $5.0 \%$ & $\begin{array}{c}6 \mathrm{~A} 321,2 \mathrm{~A} 320,4 \mathrm{~B} 737-400,1 \\
\text { B737-500 }\end{array}$ & Oct 2008 & $\begin{array}{l}\text { LCC } \\
\text { (subsidiar } \\
\text { y of OZ) }\end{array}$ & Busan \\
\hline $\begin{array}{l}\text { Eastar Jet } \\
\quad(\mathrm{ZE})\end{array}$ & $7.0 \%$ & $1.9 \%$ & $3.5 \%$ & 8 B737 & Jan 2009 & $\mathrm{LCC}$ & Not clear \\
\hline T’way (TW) & $8.5 \%$ & $1.2 \%$ & $3.5 \%$ & 7 B737-800 & Aug $2010^{3)}$ & LCC & Not clear \\
\hline $\begin{array}{l}\text { Foreign } \\
\text { carriers } \\
\end{array}$ & $0.0 \%$ & $37.4 \%$ & $26.1 \%$ & & & & \\
\hline
\end{tabular}

${ }^{1)}$ Based on passenger traffic in $2014 ;{ }^{2)}$ Subsidiary company of a conglomerate (Aekyung); ${ }^{3)}$ Started in 2004 as Hansung (Source: www.airportal.go.kr)

The Northeast Asian aviation market maintains strict bilateral agreements to constrain route development (O'Connell and Williams, 2005). Even under limited geographical and political conditions, Korean LCCs influence two incumbent carriers in the major domestic market and some intra-region routes. These limited conditions target the Northeast Asia (NE) market, which has been more liberalized than other regional markets as a measure to support Korean LCCs. Korea's economic policy is export-oriented due to the country's limited resources and market size. Aviation policies are also oriented toward international routes. Therefore, a liberalized market would offer excellent opportunities for Korean carriers if, and only if, the carriers have competitive advantages. Therefore, withdrawing is necessary this unseen regulation for new LCCs regarding designate international routes so that the necessary change can take place.

The extent to which low-cost airlines operating from secondary airports compete with full-service airlines serving the main airports in multiple-airport regions, there is an important question regarding the competitive analysis in the air transport industry (Pels et al., 2009). LCCs are growing, particularly within the Asia-Pacific region, and network airlines have reacted to this growth by creating lower-cost subsidiaries known as airlines-within-airlines (AwAs) (Homsombat et al., 2014; Pearson, Merkert, 2014). Researchers who have studied the aviation industry in Korea focus on airlines-withinairlines (AwAs) as another type of LCC business (Morrell, 2005; Gillen and Gados, 2008; Lin, 2012; Homsombat et al., 2014 and Pearson and Merkert, 2014). AwAs in North America and Europe have experienced significant failure; however, AwAs are moving to Asia and are well established in Australia, Japan, and Korea. The main element of success for LCCs is the result of ceaseless reform in provisions for air transport service, which are continued by the LCCs themselves. Studies on low-cost carriers (LCCs) are numerous, due to deregulation in the USA. Southwest Airlines has experienced success (Morrison, 2001; Vowles, 2001, etc.). The integrated/deregulated market in Europe has also seen success with Ryanair (Zhang et al., 2008; Diaconu, 2012), EasyJet (Fanning, 2007) and Air Asia (Lawton and Doh, 2012). Researchers have studied the way in which LCCs impact certain regions or countries, including Asia (Zhang et al., 2008), Malta (Graham and Dennis, 2010), and Korea (Chung and Whang, 2011). The relationship between, and the impact (or effect) on, LCCs and airports also represent a compelling topic for research (Gillen and Lall, 2004; Lei and Papatheodorou, 2010; Dennis and Graham, 2006; Francis et al., 2003). Less research has been performed on LCCs in the Asia-Pacific region due to its poorly deregulated or non-liberalized industry, especially in the Northeast Asia region. Asian aviation markets are still regulated and fragmented on a country-by-country basis (Zhang et al. 2008). Some papers have shown that LCCs in Asia have reshaped the competitive environment (O'Connell and Williams, 2005) by using the Southwest and Ryanair effect (Zhang et al., 2008).This paper contributes by studying the following: first, the comparison of the efficiency of Korean carriers; second, the reasons that AwAs dominate the domestic market and some short-haul international markets; and third, how LCCs (or AwAs) make the market and industry changes with the managerial ability and structural costsaving policies. This paper is organized as follows. Section 2 investigates airline performance using DEA and some metrics from financial statements. Section 3 analyzes the current and future state of Korean LCCs and provides some implications. Section 4 concludes with some limitation. 


\section{Method and Data}

\subsection{Airline performance measurements with DEA}

Many articles have attempted to analyze airlines' performance, efficiency or productivity in terms of operational and financial data using DEA (Good et al. 1995; Charnes et al., 1996; Fethi, 2000; Chiou and Chen, 2006; Barbot et al., 2008; Barros and Peypoch, 2009; Hong and Zhang, 2010; Zhu, 2011) and TFP (Oum and Yu, 1995). The input factors for DEA include (1) number of employees (Good et al. 1995; Oum and Yu, 1995; Charnes et al., 1996; Barbot et al., 2008; Barros and Peypoch, 2009; Hong and Zhang, 2010) and salaries (Chiou and Chen, 2009; Zhu, 2011); (2) fuel cost (Good et al. 1995; Charnes et al., 1996; Chiou and Chen, 2006; Zhu, 2011; Barbot et al., 2008 using fuel consumed; Oum and Yu, 1995 for TFP using fuel consumed) and other operating costs (Barros and Peypoch, 2009); and (3) annual cost of assets such as airplanes, ground property and equipment (Chiou and Chen, 2006; Oum and Yu, 1995), number of airplanes (Barros and Peypoch, 2009) and seats (ASKs) or supply of space (ATKs) (Charnes et al., 1996; Fethi, 2000; Hong and Zhang, 2010). Major output factors include (1) passengers and freight carried (RPKs, RTKs) (Good et al. 1995; Charnes et al., 1996; Fethi, 2000; Chiou and Chen, 2006; Barbot et al., 2008; Barros and Peypoch, 2009; Hong and Zhang, 2010; Zhu, 2011; Oum and Yu, 1995); and (2) financial performance indicators (FPIs) such as EBIT, passenger revenue and general revenue (Barros and Peypoch, 2009; Hong and Zhang, 2010; and Zhu, 2011) (Table 2).

However, FPIs are not commonly used to measure airline efficiency. Revenue growth rates of the top 150 airlines from 2002 to 2011 were $2 \%$ higher than rates from 1996 to $2011(7.9 \%)$. The average net profit margin of airlines from 2008 to 2011 was $-0.9 \%$ lower (based on data of Airline Business, Aug 2011 to Aug 2012), which means that while airlines have been increasing revenue-especially as seen from 2002 to 2011-their financial performance has been suffering. Thus, FPIs account for measurements of airline efficiency or productivity because efficiency or productivity does not guarantee profitability.

Input factors related to Korean carriers' performance measurements include the following: (a) salary, (b) fuel cost, and (c) regarding assets, material cost and some airplanes. For output factors, (a) RPKs and (b) RTKs were selected. The author chose the inputs and outputs for DEA based on literature reviews. However, in reality, large gaps in data collection exist among companies as a result of their size, ranging from global carriers to small local carriers, longevity, startups as well as companies with more than 40 years of history, and corporate structure, including companies that were listed on the stock market as well as those that were not. Therefore, this study included input and output factors if available and comparisons of the airlines according to the following criteria for input: (1) salary, (2) material cost and (3) weighted number of aircraft; and output: (1) number of passengers carried and (2) tonnage of cargo transported domestically and internationally.

Salary: The study uses salary as a major input factor instead of a number of employees. Using the number of employees as an input factor includes a bias in comparing long and short histories of companies that neglect the length of company existence. Most Korean LCCs have shorter business histories, lower salary levels, and a tendency to hire more employees than European LCCs.

Material cost comprises all assets including airplanes, ground property, and equipment listed on the balance sheet. One important element of managing a company has sufficient assets to operate and generate revenue. The authors used assets instead of operating costs (such as fuel) due to the limitations involved in acquiring the cost of all carriers on a year-by-year basis. When more assets are required, more operating costs are likewise needed to maintain the same productivity level, which is seen in all airlines. However, the material cost has limitations because it includes all nonoperating assets (such as hotels and buildings), although the authors consider that a large part of the cost is related to aircraft operation.

Weighted aircraft number considers passenger and cargo aircraft separately as input factors. Aircraft represent a valuable asset to airlines. Therefore, the authors account for an aircraft's value to calculate the operating cost. The aircraft value represents not only cost but also a major source of efficiency gains by assuming the use of simplified aircraft for LCCs, larger aircraft for FSCs and full cargo aircraft for FSCs, to lower costs (Gillen and Gados, 2008) and enhance efficiency (Hong and Zhang, 2010) with economies of scale. The authors calculated the value of the aircraft based on the average number of seats for passenger aircraft (Boeing 737 series have an average of 1, Boeing 767 series have 1.52 , Boeing 747-400 have 2.14, etc.) and space for cargo aircraft (B747-4F have 1, B747-8F have 1.22, B777F have 0.95, etc.). This variable is possibly a duplicate with material cost. However, we include this variable because LCCs have the aircraft using operational lease which is not reflected in material costs on the balance sheet.

Number of passengers carried and cargo transported tonnage for domestic and international transport was used as output factor criteria, instead of RPKs and RTKs. We believed that the RPKs and RTKs are more appropriate criteria for measurement. However, we faced limitations in acquiring data for all airlines even though researchers have used RPKs and RTKs as major output factors. Even though cargo volumes are varied airline by airline, we include it to see the whole efficiency of airlines.

With a standard DEA model-for example, CCR equation 1 (Charnes, Cooper \& Rhodes, 1978) and BCC equation 2 (Banker, Charnes \& Cooper, 1984), where $u_{r}$ is a weight of output $r(r=1,2, \ldots, k), y_{r j}$ is a scale of output $r$ of decision- 
making unit $j, v_{i}$ is a weight of input $i(i=1,2, \ldots, l)$, and $x_{i j}$ is the scale of input $i$ of decision-making unit $\mathrm{j}$-with the above-mentioned three input factors and four output factors (Table 3), we analyzed the efficiency of Korean carriers.

Table 2. Input and output factors for airlines efficiency measurement

\begin{tabular}{|c|c|c|c|c|}
\hline Author & Method & Scope & Input & Output \\
\hline $\begin{array}{l}\text { Oum and } \mathrm{Yu} \\
(1995)\end{array}$ & TFP & $\begin{array}{l}\text { World's } 23 \text { major } \\
\text { airlines }\end{array}$ & $\begin{array}{l}\text { 1) Employees } \\
\text { 2) Fuel consumed } \\
\text { 3) Annual cost for each aircraft } \\
\text { types } \\
\text { 4) Annual cost of using ground } \\
\text { property and equipment }\end{array}$ & $\begin{array}{l}\text { 1) RPKs } \\
\text { 2) Scheduled freight (RTKs) } \\
\text { 3) Mail service (RTKs) } \\
\text { 4) Unscheduled passenger and } \\
\text { freight service (RTKs) } \\
\text { 5) Incidental services }\end{array}$ \\
\hline $\begin{array}{l}\text { Good et al. } \\
\text { (1995) }\end{array}$ & $\begin{array}{c}\text { DEA CCR and } \\
\text { Stochastic frontier } \\
\text { model }\end{array}$ & $\begin{array}{l}8 \text { European and } 8 \\
\text { American airlines }\end{array}$ & $\begin{array}{l}\text { 1) Labor } \\
\text { 2) Materials (fuel, airplane and } \\
\text { non-flight equipment) }\end{array}$ & $\begin{array}{l}\text { 1) Passenger and Cargo service } \\
\text { (RTKs) } \\
\text { 2) Incidental services }\end{array}$ \\
\hline $\begin{array}{c}\text { Charnes et al. } \\
\text { (1996) }\end{array}$ & $\begin{array}{l}\text { DEA } \\
\text { Multiplicative } \\
\text { model }\end{array}$ & $\begin{array}{l}10 \text { Latin American- } \\
\text { based airlines }\end{array}$ & $\begin{array}{l}\text { 1) ASKs } \\
\text { 2) RTKs } \\
\text { 3) Fuel expenses } \\
\text { 4) Employees }\end{array}$ & 1) RPKs \\
\hline Fethi (2000) & $\begin{array}{l}\text { DEA and Tobit } \\
\text { analysis }\end{array}$ & 17 European airlines & $\begin{array}{l}\text { 1) ATKs } \\
\text { 2) Operating cost } \\
\text { 3) Non-flight assets }\end{array}$ & $\begin{array}{l}\text { 1) RPKs } \\
\text { 2) Non-passenger revenue }\end{array}$ \\
\hline Scheraga (2004) & $\begin{array}{l}\text { DEA and Tobit } \\
\text { analysis }\end{array}$ & 38 airlines & $\begin{array}{l}\text { 1) ASKs } \\
\text { 2) Operating cost } \\
\text { 3) Non-flight assets }\end{array}$ & $\begin{array}{l}\text { 1) RPKs } \\
\text { 2) Non-passenger revenue ton- } \\
\text { kilometers }\end{array}$ \\
\hline $\begin{array}{l}\text { Chiou and Chen } \\
\text { (2006) }\end{array}$ & DEA CCR / BCC & $\begin{array}{c}15 \text { routes operated by } \\
\text { a Taiwanese domestic } \\
\text { airline }\end{array}$ & $\begin{array}{l}\text { 1) Fuel cost } \\
\text { 2) Personnel cost } \\
\text { 3) Aircraft cost }\end{array}$ & $\begin{array}{l}\text { Production variables } \\
\text { 1) Number of flights } \\
\text { 2) Seat-mile Service variables } \\
\text { 1) Passenger-mile } \\
\text { 2) Embarkation passenger }\end{array}$ \\
\hline $\begin{array}{l}\text { Barbot et al. } \\
\qquad(2008)\end{array}$ & DEA BCC & $\begin{array}{l}49 \text { airlines in Europe, } \\
\text { North America, and } \\
\text { Asia Pacific }\end{array}$ & $\begin{array}{l}\text { 1) Number of workers } \\
\text { 2) Number of aircraft } \\
\text { 3) Fuel consumed }\end{array}$ & $\begin{array}{l}\text { 1) } \mathrm{ASKs} \\
\text { 2) RPKs } \\
\text { 3) RTKs }\end{array}$ \\
\hline $\begin{array}{c}\text { Barros and } \\
\text { Peypoch (2009) }\end{array}$ & $\begin{array}{c}\text { DEA CCR / BCC } \\
\text { and regression } \\
\text { analysis }\end{array}$ & 27 European airlines & $\begin{array}{l}\text { 1) Employees } \\
\text { 2) Operational cost } \\
\text { 3) Planes }\end{array}$ & $\begin{array}{l}\text { 1) RPKs } \\
\text { 2) EBIT in million euros }\end{array}$ \\
\hline $\begin{array}{c}\text { Hong and } \\
\text { Zhang (2010) }\end{array}$ & $\begin{array}{l}\text { DEA CCR and } \\
\text { Mann-Whitney } \\
\text { test }\end{array}$ & $\begin{array}{l}29 \text { airlines from } \\
\text { around the world }\end{array}$ & $\begin{array}{l}\text { 1) ASKs } \\
\text { 2) Employees }\end{array}$ & $\begin{array}{l}\text { 1) Revenues } \\
\text { 2) RPKs } \\
\text { 3) RTKs }\end{array}$ \\
\hline Zhu (2011) & Two-stage DEA & $\begin{array}{l}21 \text { American airlines } \\
\text { (including Ryanair) }\end{array}$ & $\begin{array}{l}\text { 1) Cost per available seat mile } \\
\text { 2) Salaries, wages, and benefits } \\
\text { per available seat mile } \\
\text { 3) Fuel expenses }\end{array}$ & $\begin{array}{l}\text { Intermediary output } \\
\text { 1) Load factor } \\
\text { 2) Fleet size } \\
\text { Final output } \\
\text { 1) Revenue passenger miles } \\
\text { 2) Passenger revenue }\end{array}$ \\
\hline
\end{tabular}

$$
\begin{array}{ll}
\operatorname{Max} h_{0}=\sum_{r=1}^{s} u_{r} y_{r 0} & \\
\text { s.t. } \sum_{r=1}^{s} u_{r} y_{r j}-\sum_{i=1}^{m} v_{i} x_{i j} \leq 0 & \forall j \\
\sum_{i=1}^{m} v_{r} x_{i 0}=1 & \forall r, \\
u_{r}, v_{i} \geq \varepsilon &
\end{array}
$$

$$
\begin{array}{ll}
\operatorname{Max} h_{0}=\sum_{r=1}^{s} u_{r} y_{r 0}+u_{0} & \\
\text { s.t. } \sum_{r=1}^{s} u_{r} y_{r j}-\sum_{i=1}^{m} v_{i} x_{i j}+u_{0} \leq 0 & \forall j \\
\sum_{i=1}^{m} v_{r} x_{i 0}=1 & \forall r, i \\
u_{r}, v_{i} \geq \varepsilon &
\end{array}
$$

DEA window analysis calculates the average efficiency of CCR and BCC models and scale efficiency and is useful for detecting efficiency trends of units over time (Charnes et al., 1994). Therefore, a DEA window analysis can be adapted to detect trends of DMU using panel data (Charnes et al., 1994).

The appendix table is an outcome of using the DEA, and Table 4 uses a DEA window with BCC (VRS). The efficiencies of airline groups are listed in order from full-service carriers (0.9961), which includes KE and OZ; Group 2 (0.9156), which includes AwAs (Jin Air, Air Busan) and a conglomerate subsidiary airline (Jeju Air); and Group 1 (0.8993), which includes independent LCCs (Easter and T'way). After applying a non-parametric test (Kruskal-Wallis test), the differences among the three different groups do not appear to be significant $(\mathrm{p}=0.058)$ for BCC, CCR $(0.346)$ or 
SE (0.998). The authors also attempted to find differences between Groups 1 and 2 using the Mann-Whitney test and found no significance (Table 5).

Table 3. Korean carriers performances from 2009 to 2013: Input and output data for DEA analysis

\begin{tabular}{|c|c|c|c|c|c|c|c|c|c|}
\hline \multirow{2}{*}{ Airlines } & \multirow{2}{*}{ Year } & \multirow{2}{*}{$\begin{array}{c}\text { Salary } \\
\text { Mil. Won }\end{array}$} & \multirow{2}{*}{$\begin{array}{l}\text { Material } \\
\text { Mil. Won }\end{array}$} & \multirow{2}{*}{$\begin{array}{l}\text { W. } \\
\mathrm{AC}\end{array}$} & \multirow{2}{*}{$\begin{array}{c}\text { W. } \\
\text { ACF }\end{array}$} & \multicolumn{2}{|c|}{ Pax } & \multicolumn{2}{|c|}{ Cargo } \\
\hline & & & & & & Dom & Int'l & Dom & Int'l \\
\hline \multirow{5}{*}{ Eastar } & 2013 & 25,720 & 15,611 & 8 & 0 & $1,826,964$ & 922,780 & 9,032 & 9,401 \\
\hline & 2012 & 20,824 & 46,158 & 8 & 0 & $1,619,410$ & 627,066 & 8,040 & 6,239 \\
\hline & 2011 & 15,352 & 30,397 & 6 & 0 & $1,570,161$ & 179,665 & 7,706 & 2,054 \\
\hline & 2010 & 14,307 & 31,215 & 6 & 0 & $1,795,951$ & 83,536 & 8,799 & 941 \\
\hline & 2009 & 9,202 & 28,750 & 6 & 0 & 985,043 & 654 & 4,500 & 9 \\
\hline \multirow{3}{*}{ T'way } & 2013 & 19,268 & 18,302 & 7 & 0 & $1,810,942$ & 428,842 & 8,683 & 4,257 \\
\hline & 2012 & 16,704 & 17,496 & 5 & 0 & $1,561,331$ & 331,903 & 7,424 & 3,313 \\
\hline & 2011 & 4,080 & 6,525 & 4 & 0 & $1,470,316$ & 18,922 & 6,549 & 208 \\
\hline \multirow{5}{*}{ Jin Air } & 2013 & 27,934 & 11,280 & 11 & 0 & $1,831,784$ & 930,081 & 10,534 & 9,942 \\
\hline & 2012 & 23,287 & 13,542 & 9 & 0 & $1,509,484$ & 825,731 & 8,030 & 8,801 \\
\hline & 2011 & 15,694 & 15,759 & 7 & 0 & $1,300,441$ & 454,472 & 6,459 & 4,836 \\
\hline & 2010 & 10,195 & 17,486 & 5 & 0 & $1,378,592$ & 215,383 & 0 & 2,353 \\
\hline & 2009 & 5,315 & 20,127 & 5 & 0 & $1,197,323$ & 4,198 & 0 & 45 \\
\hline \multirow{5}{*}{ Air Busan } & 2013 & 21,290 & 6,750 & 12 & 0 & $2,440,194$ & 898,185 & 17,233 & 9,241 \\
\hline & 2012 & 16,708 & 4,881 & 10 & 0 & $2,142,223$ & 609,919 & 15,430 & 6,637 \\
\hline & 2011 & 13,824 & 6,361 & 7 & 0 & $2,085,541$ & 407,350 & 15,521 & 4,361 \\
\hline & 2010 & 10,236 & 4,467 & 6 & 0 & $1,977,338$ & 133,023 & 14,186 & 1,446 \\
\hline & 2009 & 9,464 & 2,417 & 6 & 0 & $1,404,397$ & 0 & 11,249 & 0 \\
\hline \multirow{5}{*}{ Jeju Air } & 2013 & 35,076 & 40,400 & 13 & 0 & $2,867,111$ & $1,724,753$ & 15,144 & 23,461 \\
\hline & 2012 & 30,427 & 43,678 & 12 & 0 & $2,635,697$ & $1,192,888$ & 13,642 & 16,543 \\
\hline & 2011 & 24,115 & 22,583 & 10 & 0 & $2,259,761$ & 774,121 & 11,207 & 9,170 \\
\hline & 2010 & 17,591 & 27,535 & 7 & 0 & $1,707,325$ & 49,913 & 0 & 5,495 \\
\hline & 2009 & 14,022 & 97,748 & 6 & 0 & $1,353,431$ & 159,123 & 0 & 1,814 \\
\hline \multirow{5}{*}{$\begin{array}{l}\text { Asiana } \\
\text { Airlines }\end{array}$} & 2013 & 511,259 & $3,757,362$ & 94 & 11 & $4,615,744$ & $11,705,808$ & 62,223 & 829,432 \\
\hline & 2012 & 624,393 & $3,554,272$ & 94 & 11 & $4,554,256$ & $11,226,075$ & 44,715 & 772,539 \\
\hline & 2011 & 565,196 & $3,241,887$ & 85 & 9 & $4,499,516$ & $10,505,263$ & 44,212 & 760,790 \\
\hline & 2010 & 572,273 & $3,020,531$ & 86 & 9 & $4,504,818$ & $10,287,673$ & 44,530 & 765,487 \\
\hline & 2009 & 477,441 & $2,871,040$ & 82 & 9 & $4,732,168$ & $8,467,356$ & 43,934 & 668,032 \\
\hline \multirow{5}{*}{$\begin{array}{l}\text { Korean } \\
\text { Airlines }\end{array}$} & 2013 & $1,175,953$ & $14,880,090$ & 164 & 27 & $6,960,631$ & $16,645,952$ & 129,837 & $1,427,830$ \\
\hline & 2012 & $1,104,857$ & $14,880,090$ & 158 & 27 & $7,579,117$ & $16,986,675$ & 167,997 & $1,477,213$ \\
\hline & 2011 & $1,132,047$ & $14,189,336$ & 154 & 24 & $7,498,000$ & $15,289,000$ & 146,000 & $1,531,000$ \\
\hline & 2010 & $1,087,056$ & $12,600,650$ & 130 & 24 & $8,699,705$ & $15,423,041$ & 177,977 & $1,628,838$ \\
\hline & 2009 & 927,433 & $11,681,659$ & 123 & 22 & $8,388,711$ & $13,365,832$ & 195,070 & $1,439,564$ \\
\hline Min & & 4,080 & 2,416 & 4 & 0 & 985,043 & 0 & 0 & 0 \\
\hline Max & & $1,175,953$ & $14,880,090$ & 164 & 27 & $8,699,705$ & $16,986,676$ & 195,070 & $1,628,838$ \\
\hline Median & & 21,289 & 28,750 & 9 & 0 & $1,977,338$ & 774,121 & 11,249 & 8,801 \\
\hline Mean & & 259,955 & $2,582,011$ & 41 & 5 & $3,114,043$ & $4,268,945$ & 38,056 & 346,403 \\
\hline St. Dev & & 404,327 & $4,918,249$ & 54 & 9 & $2,305,519$ & $6,060,179$ & 56,571 & 563,346 \\
\hline $\mathrm{CV}$ & & 1.56 & 1.90 & 1.32 & 1.74 & 0.74 & 1.42 & 1.49 & 1.63 \\
\hline
\end{tabular}

(Source: Annual report of each company from 2009 to 2013 and www.airportal.go.kr)

\subsection{Finance and DEA analysis of Korean LCCs}

The history of the LCC market in Korea is very short. Jeju Air began an LCC in 2006 in Korea (Table 1). Although the history of Korean LCCs is short when compared to North American, European and Southeast Asian LCCs, the Korean LCC market is growing, and Korean LCCs' market share regarding three-year average revenue (2011 to 2013) is 6.4\% (1,122.2 over 17,666.8 million won, Table 6). A company sees an inevitable loss of money in its early stage due to a significant initial investment and experiences instability due to a lack of experience. Companies in the aviation industry require particularly large initial investments to acquire assets such as aircraft and equipment, even if there is a market for leasing such assets. An important factor in the early stages of a company is ensuring the competitiveness of the business to stabilize the financial structure. Korean LCCs began operating largely in 2004. The first company started was Hansung, which was recently rebranded as T'way due to management conflict that caused bankruptcy and required a change in ownership (A publisher, Yearim-Dang, acquired shares and changed the brand to T'way in 2010). Although the histories of Korean LCCs are not lengthy, some companies began seeing profits in 2010, such as Jin Air and Air Busan, subsidiaries of Korean Air and Asiana Airlines. From 2011, Jeju Air-a subsidiary of Aekyung holdings and a mid-sized Korean conglomerate-has also seen profits. Even major carriers such as Korean Air and Asiana Airlines saw revenue increase by $2.4 \%$ from 2011 to 2013 . LCCs revenue increased by $35.8 \%$ in the same timeframe. 
Table 4. DEA window analysis (based on BCC) for Korean carriers

\begin{tabular}{|c|c|c|c|c|c|c|c|c|c|c|}
\hline Group & Airlines & 2009 & 2010 & 2011 & 2012 & 2013 & Mean & $\begin{array}{c}\text { Airline } \\
\text { Mean }\end{array}$ & $\begin{array}{c}\text { Category } \\
\text { Mean }\end{array}$ & $\begin{array}{l}\text { K-W } \\
\text { Test }\end{array}$ \\
\hline \multirow{5}{*}{$\begin{array}{c}\text { Group } 1 \\
\text { (LCCs) }\end{array}$} & \multirow{3}{*}{ Eastar } & 0.5206 & 0.9083 & 0.8187 & - & - & 0.7492 & \multirow{3}{*}{0.8167} & \multirow{5}{*}{0.8993} & \multirow{20}{*}{0.058} \\
\hline & & - & 0.9083 & 0.8187 & 0.7785 & - & 0.8352 & & & \\
\hline & & - & - & 0.8187 & 0.7785 & 1 & 0.8657 & & & \\
\hline & \multirow{2}{*}{ T'way } & - & - & 1 & 1 & - & 1.0000 & \multirow{2}{*}{0.9819} & & \\
\hline & & - & - & 1 & 1 & 0.8912 & 0.9637 & & & \\
\hline \multirow{9}{*}{$\begin{array}{l}\text { Group } 2 \\
\text { (AwAs) }\end{array}$} & \multirow{3}{*}{ Jin Air } & 0.7616 & 0.8683 & 0.7594 & - & - & 0.7964 & \multirow{3}{*}{0.8485} & \multirow{9}{*}{0.9156} & \\
\hline & & - & 0.8683 & 0.7594 & 0.9427 & - & 0.8568 & & & \\
\hline & & - & - & 0.7594 & 0.9427 & 0.9746 & 0.8922 & & & \\
\hline & $\mathrm{Air}$ & 1 & 1 & 1 & - & - & 1.0000 & & & \\
\hline & $\begin{array}{c}\text { Air } \\
\text { Busan }\end{array}$ & - & 1 & 1 & 1 & - & 1.0000 & 1.0000 & & \\
\hline & & - & - & 1 & 1 & 1 & 1.0000 & & & \\
\hline & \multirow{3}{*}{ Jeju Air } & 0.6915 & 0.8492 & 0.9159 & - & - & 0.8189 & \multirow{3}{*}{0.8983} & & \\
\hline & & - & 0.8492 & 0.9159 & 0.9734 & - & 0.9128 & & & \\
\hline & & - & - & 0.9159 & 0.9734 & 1 & 0.9631 & & & \\
\hline \multirow{6}{*}{$\begin{array}{c}\text { Group } 3 \\
\text { (FSCs) }\end{array}$} & \multirow{3}{*}{$\begin{array}{l}\text { Asiana } \\
\text { Airlines }\end{array}$} & 1 & 1 & 1 & - & - & 1.0000 & \multirow{3}{*}{0.9984} & \multirow{6}{*}{0.9961} & \\
\hline & & - & 1 & 1 & 0.9929 & - & 0.9976 & & & \\
\hline & & - & - & 1 & 0.9929 & 1 & 0.9976 & & & \\
\hline & \multirow{3}{*}{$\begin{array}{c}\text { Korean } \\
\text { Air }\end{array}$} & 1 & 1 & 0.9838 & - & - & 0.9946 & \multirow{3}{*}{0.9937} & & \\
\hline & & - & 1 & 0.9838 & 1 & - & 0.9946 & & & \\
\hline & & - & - & 0.9838 & 1 & 0.9910 & 0.9918 & & & \\
\hline
\end{tabular}

Table 5. Nonparametric test with the result of DEA CCR, BCC and SE for Korean carriers

\begin{tabular}{ccc}
\hline & M-W test between Group 1 \& 2 & K-W Test among Group 1, 2 \& FSC \\
\hline CCR (CRS) & 0.641 & 0.346 \\
BCC (VRS) & 0.594 & 0.058 \\
SE & 0.947 & 0.998 \\
\hline
\end{tabular}

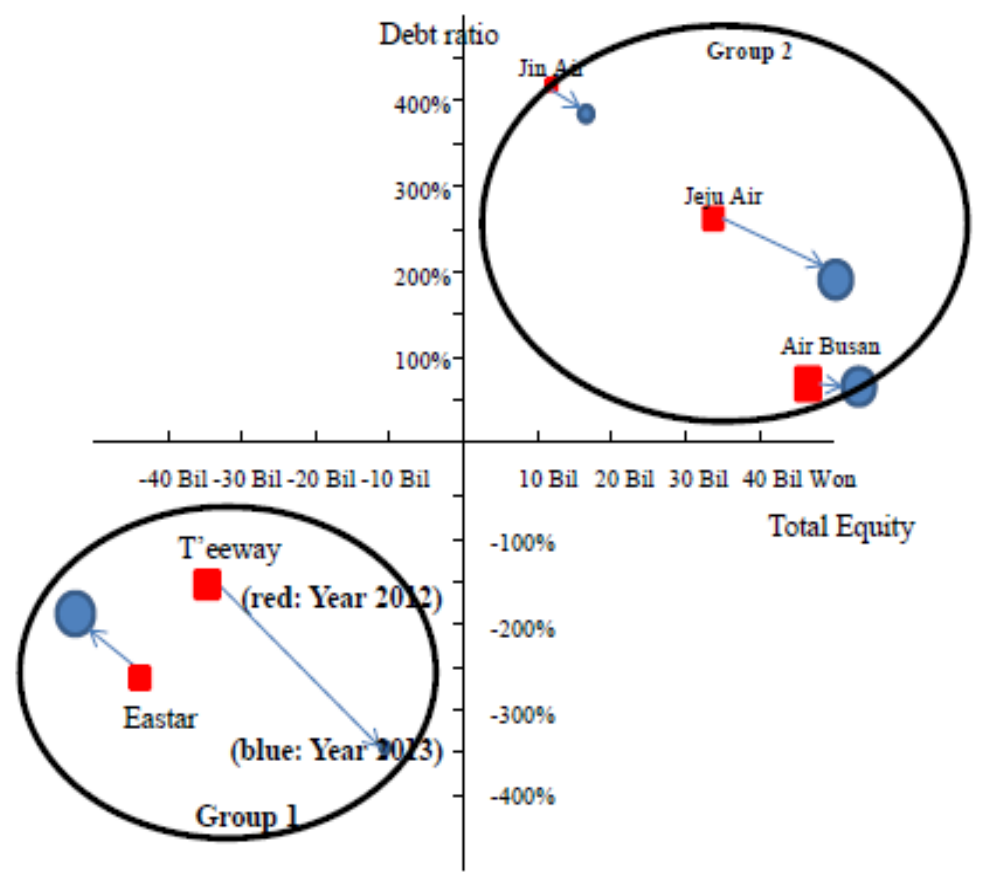

Figure 1. Korean LCCs' financial stability. (Data source: Annual report of each company)

Regarding financial stability, two types of LCCs exist in Korea. LCCs such as Jin Air, Air Busan, and Jeju Air has earned profits from either 2010 or 2011 to 2013 (the final year in which the author collected data), and profits were also be expected in 2014. Second, Eastar and T'way have seen decreases in profits since starting operations, especially so for T'way in 2013 (representing a loss of 14 billion Korean won). Interestingly, the second type of LCC (including Eastar 
and T'way) is an independent company without any relationships to existing business entities. These two groups show a decided difference regarding debt ratio (total liability over total equity, Table 4). The average debt ratio of the independent LCCs is $-255 \%$ (-262.9\% for Eastar and $-248.1 \%$ for T'way) from 2011 to 2013(The data for the study were mostly collected from dart.fss.or.kr. DART stands for data analysis, retrieval and transfer system and is operated by the Korean FSS (Financial Supervisory Service). Annual reports of each company were used from 2009 to 2013. Based on whether data were available for most of the airlines, factors to measure the efficiency used DEA). Worse still are their negative net profit margins. Based on an analysis of financial stability and ownership of these two types of LCCs, the first type (group 1 in figure 1) includes independent LCCs such as Eastar and T'way, which represent a 40\% share in the LCC market. The first group has seen higher rates of growth (36.4\%) than AwAs (35.5\%) and full-service carriers (2.4\%), but their net profit margins have been negative since their inception, except T'way in 2013. Although profitability has improved, equities are impaired, and the debt ratio is negative. The second group of LCCs (group 2 in figure 1) represents AwAs, or subsidiaries of conglomerates such as the Korean Air Group (Jin Air), the Asiana-Kumho Group (Air Busan) and the Aekyung Group (Jeju Air). Revenue growth for the $2^{\text {nd }}$ group is slightly lower than for the $1^{\text {st }}$ group, but financial stability for the former is steady, as is profitability and equity.

Table 6. Korean carriers' financial performance

\begin{tabular}{|c|c|c|c|c|c|c|c|c|}
\hline Airline & Year & Rev.(1) & $\begin{array}{c}\text { Rev \% of } \\
\text { changes }\end{array}$ & Net Profit (1) & $\begin{array}{c}\text { Net Profit } \\
\text { Margin (\%) }\end{array}$ & $\begin{array}{c}\text { Debt Ratio } \\
(\%)\end{array}$ & Equity (1) & $\begin{array}{c}\text { Salary/ } \\
\text { WLU (2) }\end{array}$ \\
\hline \multirow{4}{*}{ Eastar } & 2013 & 254.3 & 29.5 & -16.7 & -6.6 & -171.9 & -60.4 & 841 \\
\hline & 2012 & 196.4 & 61.5 & -22.9 & -11.6 & -269.2 & -43.7 & 834 \\
\hline & 2011 & 121.6 & 10.5 & -26.9 & -22.1 & -344.6 & -20.6 & 789 \\
\hline & Mean & 190.8 & 32.2 & -22.2 & -13.7 & -262.9 & -41.6 & 821 \\
\hline \multirow{4}{*}{ T'way } & 2013 & 166.8 & 21.6 & 14.0 & 8.4 & -366.6 & -10.1 & 774 \\
\hline & 2012 & 137.2 & 67.8 & -15.8 & -11.5 & -174.0 & -33.9 & 794 \\
\hline & 2011 & 81.8 & - & - & - & -203.8 & -18.4 & 246 \\
\hline & Mean & 128.6 & 42.8 & -0.9 & -2.1 & -248.1 & -20.8 & 605 \\
\hline \multicolumn{2}{|c|}{ Eastar+T'way (1) } & $40 \% *$ & 36.4 & & -9.2 & -255.0 & -31.2 & 713 \\
\hline \multirow{4}{*}{ Jin Air } & 2013 & 283.3 & 14.5 & 4.2 & 1.5 & 399.0 & 17.8 & 910 \\
\hline & 2012 & 247.5 & 45.3 & 9.8 & 4.0 & 426.7 & 13.3 & 897 \\
\hline & 2011 & 170.3 & 46.8 & 2.9 & 1.7 & $1,348.7$ & 4.2 & 804 \\
\hline & Mean & 233.7 & 34.7 & 5.6 & 2.4 & 724.8 & 11.8 & 870 \\
\hline \multirow{4}{*}{ Air Busan } & 2013 & 277.9 & 25.9 & 4.6 & 1.7 & 66.2 & 56.2 & 574 \\
\hline & 2012 & 220.8 & 24.3 & 4.5 & 2.0 & 73.6 & 51.6 & 494 \\
\hline & 2011 & 177.6 & 47.1 & 4.7 & 2.6 & 59.2 & 47.5 & 461 \\
\hline & Mean & 225.4 & 32.0 & 4.6 & 2.1 & 66.3 & 51.8 & 510 \\
\hline \multirow{4}{*}{ Jeju Air } & 2013 & 432.3 & 26.7 & 19.3 & 4.5 & 203.3 & 52.6 & 687 \\
\hline & 2012 & 341.2 & 32.4 & 5.2 & 1.5 & 268.6 & 33.2 & 715 \\
\hline & 2011 & 257.7 & 63.6 & 16.8 & 6.5 & 253.1 & 28.6 & 715 \\
\hline & Mean & 343.7 & 40.0 & 13.8 & 4.1 & 236.0 & 38.1 & 706 \\
\hline \multicolumn{2}{|c|}{ Jin+Busan+Jeju (2) } & $60 \% *$ & 35.5 & & 2.9 & 355.7 & 33.9 & 695 \\
\hline \multicolumn{2}{|c|}{$(1)+(2)$} & $6.4 \% * *$ & 35.8 & & -1.6 & 116.8 & 9.7 & 702 \\
\hline \multirow{4}{*}{ Asiana Airlines } & 2013 & $5,723.5$ & -2.8 & -114.7 & -2.0 & 676.3 & 903.3 & 2,805 \\
\hline & 2012 & $5,887.9$ & 5.0 & 62.5 & 1.1 & 505.7 & $1,004.9$ & 3,545 \\
\hline & 2011 & $5,609.4$ & 10.6 & -29.9 & -0.5 & 567.3 & 861.3 & 3,374 \\
\hline & Mean & $5,740.3$ & 4.1 & -27.4 & -0.5 & 583.1 & 923.2 & 3,241 \\
\hline \multirow{4}{*}{ Korean Air } & 2013 & $11,712.4$ & -4.5 & -383.6 & -3.3 & 736.5 & $2,740.2$ & 4,457 \\
\hline & 2012 & $12,261.7$ & 3.9 & 256.4 & 2.1 & 691.0 & $2,904.4$ & 4,024 \\
\hline & 2011 & $11,805.3$ & 3.0 & -366.8 & -3.1 & 708.6 & $2,769.0$ & 4,442 \\
\hline & Mean & $11,926.5$ & 0.7 & $6,164.7$ & -1.5 & 712.0 & $2,804.5$ & 4,307 \\
\hline \multicolumn{2}{|c|}{ Asiana+Korean Air } & $95.6 \% * *$ & 2.4 & & -1.0 & 647.6 & $1,863.9$ & 3,774 \\
\hline
\end{tabular}

Unit (1) billion Korean won, (2) Korean won * Market share regarding three-year average revenue in the LCC market

** Market share regarding three-year average revenue in the aviation market, including LCC and FSC

(Source: Annual report of each company from 2012 to 2014)

\section{Result}

Cost leadership through low costs (Porter, 1980), reducing costs (Attali, 1991), lower costs (Kim et al., 2005) and discounting (Bosshart, 2006) is becoming the most important social demand in a rapidly changing world. However, low cost does not equal low prices for goods or low-quality products. Lower costs are a summation of activities of innovation based on customer needs conducted to increase a customer's willingness to pay by creating value for the customer. In Korea, the LCC market is dominated by AwAs, created to serve competitive responses from full-service carriers, including the elimination of unprofitable routes. These routes include major domestic and short-haul international routes, 
especially those serving leisure destinations with fare reductions. FSCs introduced AwAs to keep pace with fiercely competitive business environments. The creation of AwAs may provide a strategic mechanism to counteract unprecedented LCC expansion and thereby protect existing markets (Lin, 2012). However, it is hard to observe AwAs' strategies regarding cost-effective operations, market focus and product differentiation through process innovation for passenger, cargo and other related businesses in Korea. Major routes were transferred to AwAs by their parent companies, ceding unprofitable and highly competitive routes with lower prices. Furthermore, the AwAs' and LCC's expansion in Korea is based on benefits provided by regional airports. The airports wish to attract more airlines, including providing exemptions on landing, parking and lighting charges for the first three years; reducing the closed period from eight hours (22:00-06:00) to five hours (24:00-05:00) at Daegu Airport; eliminating the closed period at Cheongju Airport; offering free visas for Chinese visitors at Daegu, Yangyang, Jeju and Cheongju Airports; and providing subsidies from local governments to cover costs at Cheongju and Yangyang Airports. It is hard to exploit by AwAs or LCCs regarding either cost-effectiveness or added customer value (Gillen and Gados, 2008), or both and structural drivers are not as easy in the short- and medium-term (Shank and Govindarajan, 1993). The AwAs' business strategy was introduced in the US and Europe in the 1990s (Pearson and Merkert, 2014). However, many researchers have noted that AwAs failed in these markets because of unionized labor forces (Morrell, 2005), incompatibility with parent carriers (Graf, 2005), cannibalization in markets (Graham and Vowls, 2006), and poor coordination between low-cost and full-service business models, resulting in further cannibalization (Gillen and Gados, 2008). Pearson and Merkert (2014) revealed that AwAs' yield and load factors are lower than those of their parent companies. The reasons that AwAs disappeared are (1) illdefined strategies and a lack of decisive leadership, (2) late market entrance and the need to achieve market dominance, (3) excessive management control from parent companies and insufficient dissimilarity from parent companies and (4) higher costs and less efficiency in comparison with LCC competitors. However, a dual-brand strategy, with one brand using low costs and a full-service brand, offers benefits for quality, a competitive effect, such as with the case of Korean AwAs, and successful operation in the Australian domestic market (Homsombat et al., 2014).

\section{Conclusion}

Various analyses of airline production efficiency use DEA based on cross-sectional data. When the companies' number of years in operation is not considered, the efficiency results derived using DEA can be biased. To overcome this problem, this paper applies a DEA window analysis utilizing panel data in a sample of Korean LCCs to calculate relative efficiency. The results suggest that estimated rates of Korean airlines' efficiency fluctuate over time. However, FSCs' efficiency rates are higher than those of LCCs (economies of scale) because FSCs largely serve more profitable routes such as international routes (Oum et al., 1997; Scheraga, 2004), while LCCs serve mainly domestic and short-haul international markets and cargo (Hong and Zhang, 2010). Researchers indicate that there is significant differentiation in services provided by FSCs and LCCs (Fu, Dresner and Oum, 2011). However, this research contributes to measuring the efficiency LCCs by categorizing independent LCCs and AwAs.

Comparing two groups of LCCs, such as independent LCCs and AwAs, AwAs subsidized by existing carriers (fullservice carriers) or conglomerates are more efficient than independent LCCs because of the halo effect of FSCs. The most difficult element facing independent LCCs is impairment of capital, as their market is somewhat limited domestically and internationally, in the absence of economies of scale due to the regulated environment and a reduced capability in the development of markets (economies of experience). In North America (Zou, Hansen, 2012), Europe (Bilotkach et al., 2015) and Southeast Asia (Hanaoka et al., 2014), LCCs play a major role in supplying transportation for increasing numbers of tourists and business travelers. LCCs create new tourism demand and induce competition within the air transport industry as well. According to Bieger and Wittmer (2006), LCCs currently attract not only low-fare passengers with high elasticity in price but also passengers-depending on the number of flights-with high elasticity in travel time. However, independent LCCs in Korea are suffering, due not only to inefficiency but also to financial strain. AwAs, positioned under the umbrella of full-service carriers, are expanding. Their strategies are limited due to cannibalization by parent companies.

According to Lin (2012), retaining a hub-and-spoke network is logical if passengers do not perceive significant differentiation between one-stop and non-stop service and if the via-hub time cost is sufficiently small. If differentiation is substantial, then adoption of an AwA to shift to a mixed (point-to-point) network is optimal. Expand the network in this region is possible through innovative processes and negotiable capabilities with airports and to promote potential market growth to gain the same impact as full liberalization (Hanaoka et al., 2014). LCCs in Korea have to exhibit product differentiation through process design that enables them to operate at a much lower cost per unit of output when compared with airlines that only use price differentiation under the umbrella of FSCs.

This study had certain limitations in analyzing LCCs in Korea because the authors are using the data of the early stage of LCCs from 2009 to 2013. There is going to be strong LCCs' growth from 2014 that is driven by declining fuel price and surging tourism demand especially, neighborhood countries such as China, Japan as well as the Southeast Asian countries. Also, with the experiences from failures at the beginning stage, LCCs in Korea are becoming stronger financially and solid for marketing skills. However, there are too many players in the small and regulated market. 
Therefore, further research is needed with recent data.

\section{References}

Airline Business from August 2001 to August 2012.

Attali, J., 1991. Millennium-Winners and Losers in the Coming World Order. New York: Random House.

Banker, R. D., Charnes, A., Cooper, W. W., 1984. Models for estimating technical and scale efficiencies in data envelopment analysis. Management Sciences 30, 1078-1092.

Barbot, C., Costa, A., Sochica, E., 2008. Airlines performance in the new market context: A comparative productivity and efficiency analysis. Journal of Air Transport Management 14, 270-274.

Barros, C., Peypoch, N., 2009. An evaluation of European airlines' operational performance. International Journal of Production Economics 122, 525-533.

Bilotkach, V., Gaggero, A., Piga, C.A., 2015. Airline pricing under different market conditions: Evidence from European low-cost carriers. Tourism Management 47, 152-163.

Bosshart, D. 2006. Cheap? - The Real Cost of Living in a Low Price. London/Philadelphia: Low Wage World, Kogan Page.

Charnes, A., Cooper, W.W., Rhodes, E., 1978. Measuring efficiency of decision making units. European Journal of Operational Research 3, 429-444.

Charnes, A., Cooper, W.W., Seiford, L.M., 1994. Data Envelopment Analysis: Theory, Methodology, and Applications Extension to DEA Models, (A. Charnes, W.W. Cooper, A.Y. Lewin, and L.M. Seiford (Eds.)). Norwell: Kluwer Academic Publishers.

Charnes, A., Gallegos, A., Li, H., 1996. Robustly efficient parametric frontiers via multiplicative DEA for domestic and international operations of the Latin American airline industry. European Journal of Operational Research 88, 525-536.

Chiou, Y.C., Chen, Y.H., 2006. Route-based performance evaluation of Taiwanese domestic airlines using data envelopment analysis. Transportation Research Part E: Logistics and Transportation 42, 116-127.

Fu, X., Dresner, M., Oum, T.H., 2011. Effects of transport service differentiation in the U.S. domestic airline market. Transportation Research Part E: Logistics and Transportation 47, 297-305.

Gillen, D., Gados, A., 2008. Airlines within airlines: Assessing the vulnerabilities of mixing business models. Research in Transportation Economics 24, 25-35.

Good, D.H., Roller, L.H., Sickles, R.C., 1995. Airline efficiency differences between Europe and the U.S.: Implications for the pace of EC integration and domestic regulation. European Journal of Operational Research 800, 508-518.

Graham, B., Vowles, T.M., 2006. Carriers within carriers: A strategic response to low-cost airline competition. Transport Reviews: A Transnational Transdisciplinary Journal 26, 105-126.

Hanaoka, S., Takebayashi, M., Ishikura, T., Saraswati, B., 2014. Low-cost carriers versus full-service carriers in ASEAN: The impact of liberalization policy on competition. Journal of Air Transport Management 40, 96-105.

Hong. S.J., Zhang, A., 2010. An efficiency study of airlines and air cargo/passenger divisions: A DEA approach. World Review of Intermodal Transportation Research 3, 137-149.

Homsombat, W., Lei, Z., Fu, X., 2014. Competitive effects of the airline-within-airlines strategy: Pricing and route entry patterns. Transportation Research Part E: Logistics and Transportation 63, 1-16.

Johnston, A., Ozment, J., 2013. Economies of scale in the U.S. airline industry. Transportation Research Part E: Logistics and Transportation 51, 95-108.

Kim, W.C., Mauborgne, R., 2005. Blue Ocean Strategy: How to Create Uncontested Market Space and Make the Competition Irrelevant. Boston: Harvard Business School Press.

Lawton, T., Doh, J., 2010. The ascendance of Air Asia: Building a successful budget airline in Asia. Ontario, Canada: Richard Ivey School of Business.

Lin, M.H. 2012. Airlines-within-airlines strategies and existence of low-cost carriers. Transportation Research Part E: Logistics and Transportation 48, 637-651.

Morrell, P. 2005. Airlines within airlines: An analysis of U.S. network airline responses to low cost carriers. Journal of Air Transport Management 11, 303-312.

O'Connell, J.F., Williams, G., 2005. Passengers' perception of low cost airlines and full service carriers: A case study involving Ryanair, Aer Lingus, Air Asia and Malaysia Airlines. Journal of Air Transport Management 11, 259-272.

Oum, T.H., Yu, C., 1997. Winning Airlines: Productivity and Cost Competitiveness of the World's Major Airlines. Boston/Dordrecht/ London: Kluwer Academic Publishers.

Park, Y., Ha, H.-K., 2006. Analysis of the impact of high-speed railroad service on air transport demand. Transportation Research Part E: Logistics and Transportation 42, 95-104.

Papatheodorous, A., Lei, A., 2006. Leisure travel in Europe and airline business models: A study of regional airports in Great Britain. Journal of Air Transport Management 12, 47-62.

Pels, E., Njegovan, N., Behrens, C., 2009. Low-cost airlines and airport competition. Transportation Research Part E: Logistics and Transportation 45, 335-344.

Pearson, J., Merkert, R., 2014. Airlines-within airlines: A business model moving East. Journal of Air Transport Management 38, 2126.

Porter, M. 1980. Competitive Strategy-Techniques for Analyzing Industries and Competitors. New York: The Free Press.

Shank, J., Govindarajan, V., 1993. Strategic cost management: The new tool for competitive advantage. New York: The Free Press.

Wan, Y., Ha, H.-K., Yoshida, Y., Zhang, A., 2016. Airlines' reaction to high-speed rail entries: Empirical study of the Northeast Asian market. Transportation Research Part A: Policy \& Practice 94, 532-537.

Zhang, A., Hanaoka, S., Inamyra, I., Ishikura, T., 2008. Low-cost carriers in Asia: Deregulation, regional liberalization, and secondary airports. Research in Transportation Economics 24, 36-50. 
Zhu, J. 2011. Airlines performance via two-stage network DEA approach. Journal of CENTRUM Cathedra 4, 260-269.

Zou, B., Hansen, M. 2012. Impact of operational performance on air carrier cost structure: Evidence from U.S. airlines. Transportation Research Part E: Logistics and Transportation 48, 1032-1048.

Korean air transport statistics. Retrieved from <http://www.airportal.go.kr>.

\section{Appendix}

Table A1. DEA analysis

\begin{tabular}{|c|c|c|c|c|c|c|c|c|}
\hline Airli & & 2009 & 2010 & 2011 & 2012 & 2013 & Avg. & St. Dev. \\
\hline \multirow{4}{*}{ Eastar } & CCR & 0.4488 & 0.8487 & 0.7885 & 0.7773 & 1 & 0.7727 & 0.2016 \\
\hline & BCC & 0.5206 & 0.9083 & 0.8187 & 0.7785 & 1 & 0.8052 & 0.1806 \\
\hline & Scale & 0.8621 & 0.9344 & 0.9631 & 0.9985 & 1 & 0.9516 & 0.0570 \\
\hline & RTS & DRS & DRS & DRS & DRS & CRS & & \\
\hline \multirow{4}{*}{ T'way } & CCR & & & 1 & 1 & 0.8687 & 0.9562 & 0.0758 \\
\hline & $\mathrm{BCC}$ & & & 1 & 1 & 0.8912 & 0.9637 & 0.0628 \\
\hline & Scale & & & 1 & 1 & 0.9748 & 0.9916 & 0.0145 \\
\hline & RTS & & & CRS & $\mathrm{CRS}$ & DRS & & \\
\hline \multirow{4}{*}{ Jin Air } & CCR & 0.6515 & 0.8618 & 0.703 & 0.9109 & 0.9722 & 0.8199 & 0.1372 \\
\hline & $\mathrm{BCC}$ & 0.7616 & 0.8683 & 0.7594 & 0.9427 & 0.9746 & 0.8613 & 0.0998 \\
\hline & Scale & 0.8554 & 0.9925 & 0.9257 & 0.9663 & 0.9975 & 0.9475 & 0.0588 \\
\hline & RTS & DRS & IRS & IRS & IRS & IRS & & \\
\hline \multirow{4}{*}{$\begin{array}{c}\text { Air } \\
\text { Busan }\end{array}$} & CCR & 1 & 1 & 1 & 1 & 1 & 1 & 0.0000 \\
\hline & $\mathrm{BCC}$ & 1 & 1 & 1 & 1 & 1 & 1 & 0.0000 \\
\hline & Scale & 1 & 1 & 1 & 1 & 1 & 1 & 0.0000 \\
\hline & RTS & CRS & CRS & CRS & CRS & CRS & & \\
\hline \multirow{4}{*}{ Jeju Air } & CCR & 0.6595 & 0.8328 & 0.8474 & 0.9028 & 1 & 0.8485 & 0.1244 \\
\hline & $\mathrm{BCC}$ & 0.6915 & 0.8492 & 0.9159 & 0.9734 & 1 & 0.8860 & 0.1232 \\
\hline & Scale & 0.9537 & 0.9807 & 0.9252 & 0.9275 & 1 & 0.9574 & 0.0328 \\
\hline & RTS & DRS & DRS & DRS & DRS & CRS & & \\
\hline \multirow{4}{*}{$\begin{array}{c}\text { Asiana } \\
\text { Airlines }\end{array}$} & CCR & 0.9742 & 1 & 1 & 0.9582 & 1 & 0.9865 & 0.0194 \\
\hline & $\mathrm{BCC}$ & 1 & 1 & 1 & 0.9929 & 1 & 0.9986 & 0.0032 \\
\hline & Scale & 0.9742 & 1 & 1 & 0.9651 & 1 & 0.9879 & 0.0169 \\
\hline & RTS & DRS & CRS & CRS & DRS & CRS & & \\
\hline \multirow{4}{*}{$\begin{array}{c}\text { Korean } \\
\text { Air }\end{array}$} & CCR & 1 & 1 & 0.9042 & 0.895 & 0.8319 & 0.9262 & 0.0729 \\
\hline & $\mathrm{BCC}$ & 1 & 1 & 0.9838 & 1 & 0.9917 & 0.9951 & 0.0073 \\
\hline & Scale & 1 & 1 & 0.9191 & 0.895 & 0.8389 & 0.9306 & 0.0697 \\
\hline & RTS & CRS & CRS & DRS & DRS & DRS & & \\
\hline \multirow{3}{*}{ Mean } & CCR & 0.7890 & 0.9239 & 0.8919 & 0.9206 & 0.9533 & 0.8957 & 0.0635 \\
\hline & $\mathrm{BCC}$ & 0.8290 & 0.9376 & 0.9254 & 0.9554 & 0.9796 & 0.9254 & 0.0576 \\
\hline & Scale & 0.9409 & 0.9846 & 0.9619 & 0.9646 & 0.9730 & 0.9650 & 0.0161 \\
\hline \multirow{3}{*}{ St. Dev. } & CCR & 0.2344 & 0.0839 & 0.1180 & 0.0771 & 0.0719 & 0.1170 & 0.0680 \\
\hline & BCC & 0.2031 & 0.0709 & 0.0993 & 0.0808 & 0.0401 & 0.0988 & 0.0621 \\
\hline & Scale & 0.0660 & 0.0257 & 0.0378 & 0.0410 & 0.0656 & 0.0472 & 0.0179 \\
\hline
\end{tabular}

